\title{
ETHICS IN THE LEGAL PROFESSION: THE ISSUE OF ACCESS
}

\section{ESMERALDA M.A. THORNHILL'}

The author issues a clarion call to the legal profession to address the issue of access in a substantive manner. The author feels that both law schools and the legal profession are still dominated by a patriarchal, Eurocentric perspective - one that is clearly at odds with Canada's commitment to equality and the reality of its ever more ethnically diverse demography.
L'auteure exhorte le barreau d̀ traiter sérieusement de la question de l'accès. L'auteure estime que, tant au niveau des facultés que dans la pratique, le droit reste dominé par une perspective patriarcale, eurocentrique - qui est clairement en porte-à-faux avec la dédication canadienne d'egalité et la réalité d'une démographie pluriethnique de plus en plus diversifiée.

\section{TABLE OF CONTENTS}

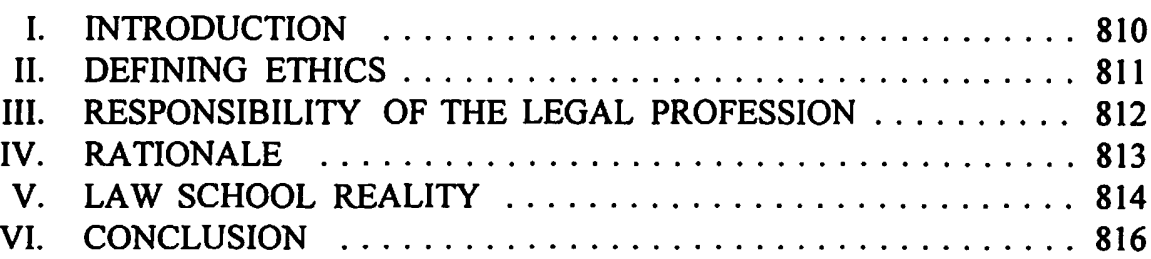

\section{INTRODUCTION}

We must all welcome this timely if rather overdue forum on Ethics in the Legal Profession because it offers us the opportunity to examine simultaneously both our profession and our roles as agents of the institution of law, in the hope that together we may determine the parameters of our professional responsibility with regard to equity. For certain "Visible Minorities"' — and I use the term guardedly — identifiable gaps exist in obtaining justice, ${ }^{2}$ particularly for issues involving "race." These gaps themselves represent a fundamental betrayal of equality. ${ }^{3}$ And the legal profession is

Agente d'éducation, Commission des droits de la personne du Québec. The author retains the copyright to this article.

1 Terminology is a problem when it comes to nomenclature. A plethora of convenient labels abound; however, they all deconstruct and decode to read We-They/Us-Them. I have resorted to using "..." each time I refer to "racialized" groups in order to show how the psycho-social reality of "race" firstly socially constructs and then proceeds to exclude perceived "otherness." For a more detailed discussion, see E.M.A. Thornhill, Cultural Minorities in the School: Some Thought-Sharing and Mind S-T-R-E-T-C-H-I-N-G (Discussion paper presented to the Quebec Association for Intercultural Education) (Montreal: Education Department, Commission des droits de la personne du Québec, 1984); see also K. Williams Crenshaw, "Foreword: Toward A Race Conscious Pedagogy in Legal Education" (1990) 112 Nat'l Black L.J. 1 at 3. 
obliged to address such gaps since law and the legal profession are accountable to "race."4

\section{DEFINING ETHICS}

"Ethics," coming from the Greek word "ethos" and the Latin "mores," refers to those customary and prescribed communal living standards broadly considered to be good. ${ }^{5}$ Simply put, ethics refers to a code of conduct or a yardstick by which individual actions are tested against societally acceptable standards of honesty, integrity, fairness and good faith. ${ }^{6}$ Ethics provide the grounding which enables individuals to make sensible decisions in a complex, challenging and everchanging business environment. ${ }^{7}$

Ethics have become an everyday reality for today's business and professional world. They comprise the standards we set to determine decision-making, including both the minimal obligations which we must satisfy as well as those ideals we deem worth pursuing. ${ }^{8}$ "Through a legal fiction, a corporation is regarded as a person in relation to the law; but in reality, it is more than this abstract concept; it has a human dimension and morality brought to it by its owners, management, and employees." 9 So too the legal profession. For, like the corporate entity, it is endowed with a human dimension and possesses a morality brought to it by its agents. The legal profession, like a corporation, has an ethical reputation; it is judged by those it deals with - members, clients, students, courts, the public - against the same ethical standards as individuals. In fact, our courts already ascribe intent, motive, purpose and negligence to corporations. And, in the same way, a transfer of thinking from individual values to corporate decisions happens within the legal profession, both consciously and unconsciously. Unconsciously because, as individuals, we members of the profession each bring morality with us to the profession; and consciously, through the leadership and well-established commitment to high ethical standards in all relationships that the legal profession exacts. ${ }^{10}$

In light of the foregoing, the issue of ethics in the legal profession must be studied and understood within the context of the de facto real-life situations which people face every day. " For no concept of professional ethics should be so sanitized and washed out that it is artificially isolated from the structure of the profession as a discrete field

See generally E.M.A. Thornhill, "Regard sur le racisme: perspectives juridiques à partir d'un vécu noir" (1993) 6:1 R.J.F.D. 1 at 1-24; Justice B. Wilson, Touchstones For Change: Equality, Diversity, and Accountability. Report of the Canadian Bar Association Task Force on Gender Equality in the Legal Profession (Ottawa: Canadian Bar Association, 1993) at 17-19; J.C. Sparks, "Women of Colour in the Legal Profession" Appendix 10 to the Report of the Canadian Bar Association Task Force on Gender Equality in the Legal Profession, ibid. F. Bird \& J. Gandz, Good Management: Business Ethics in Action (Scarborough, Ontario: PrenticeHall Canada Inc., 1991) at 5.

Ibid. at $\mathbf{v}$.

lbid.

Ibid. at 3.

Ibid. at 10.

Ibid.

Ibid. at vi. 
unto itself..$^{12}$ In other words, we must "walk our talk" and translate our rhetoric and discourse on principles into everyday policies and practices. And inevitably, the residual responsibility for much of the profession's ethical load falls to the structures of our profession. ${ }^{13}$

\section{RESPONSIBILITY OF THE LEGAL PROFESSION}

Since laws represent a codification of the expectations and standards of behaviour deemed appropriate by a society, the legal profession ipso facto has an exemplary obligation to itself be the epitome of ethical behaviour. ${ }^{14}$ More and more, we are being forced to be acutely conscious of our legal ethics, of those usages or customs and behaviour among our membership which involve the moral obligations and professional duties we hold towards one another, towards our clients and towards the courts. Put another way, legal ethics concerns our profession's accountability to pre-set standards of societal conduct.

Our global village is fast shrinking and Canada's social fabric is undergoing irreversible change. The demographic face of Canada has already changed considerably and continues to change. Charter protection has opened up new vistas and avenues on rights entitlement. And our citizenry, Monsieur and Madame Tout-le-Monde, are demanding real and meaningful participation in Canadian society. In short, we in Canada have affirmed and promoted a culture of equality and equity, both at home and abroad, at varying levels. ${ }^{15}$

Equality and equity now constitute explicit elements in our social code of conduct. In response to these new imperatives, corporations and institutions in both the private and public sector are now trying to realign their standards of behaviour, in accordance with this new reality. Law too must change. Like other institutions, law must be transformed to truly embrace new notions of equality, fairness and appreciation for the richness of diversity. ${ }^{16}$ Concepts of social justice, coupled with the common law tool of equity, compel the legal profession to pursue equality which will promote, enhance and value cultural, ethnic, racial and sexual diversity. This will enable heretofore excluded groups to be productive, successful, and satisfied members of the legal profession. ${ }^{17}$

Our profession is being forced to confront new realities. "The patent injustice of discriminatory practices and systemic barriers are impossible to ignore."18 We in the profession know and are increasingly being made aware of the prevailing inequities. For example, we are being forced to confront the conspicuous dearth of "Visible Minorities" in the profession at all levels. We are being forced to acknowledge the absence of

H.P. Glenn, "Professional Structures and Professional Ethics" (1990) 35 McGill L.J. 424 at 425-26.

Ibid. at 426.

Wilson, supra note 4 at $17-19$.

Ibid. at 9-20.

File, supra note 2 at $\mathrm{xv}$.

Sparks, supra note 4 at 1 .

Wilson, supra note 4 at 17 . 
excluded or marginalized voices from the construction and articulation of legal doctrine, theory and discourse. We are being forced to critically examine and reassess the paradigms, perspectives and values that underpin our current legal constructs and assumptions. We are being forced to understand that the legal profession must now redefine itself along more inclusive, participatory and democratic lines that are not exclusively Eurocentric, male and white, but also embrace a multiplicity and diversity of experiences - themselves configured and socially constructed by factors of "race," colour, sexual orientation, disability, gender, ethnicity.... We are being forced to acknowledge and address racism and other tangible inequities that exist right now in our society as well as in our institutions. We are being forced to be accountable for the authority and actions designed to end such discrimination and redress such inequalities. ${ }^{19}$

Trained and accustomed to working with evidence, can we deny "the raw fact of continuing racial injustice"? ${ }^{20} \mathrm{We}$ in the profession clearly know that once racially excluded groups, for example, exercise their rights to participate at all levels of the legal system, both the substantive law and its interpretation, application and enforcement will move closer towards protecting the legal rights of all citizens. ${ }^{21}$

\section{RATIONALE}

I posit the following argument:

(1) Equality and equity issues are already priorities on this country's social and public policy agendas.

(2) Therefore, equality and equity fall well within the ambit of ethical behaviour, both for law as an institution and for the legal profession.

(3) Yet, resistance from the profession has already emerged in the form of:

- refusal to be accountable for our profession's action or inaction;

- playing ostrich ${ }^{22}$ in the face of acts of omission or commission vis-à-vis equity; and

- failure to respond proactively, or refusal to set about redressing inequities.

(4) Consequently, we must perforce conclude that all such forms of resistance, ipso facto, constitute unethical behaviour for the profession and should be deemed professional misconduct.

To ignore or dismiss the material reality of inequality and inequity that runs rife in the evidence which surrounds us, according to the very standards set by our profession,

Whether we admit it or not, human rights legislation, affirmative action measures, employment equity programs and regulations are "correctives" whose drafting, interpretation, application and enforcement, more often than not, fall to the legal profession.

R. Kennedy, "Race Relations Law and the Tradition of Celebration: The Case of Professor Schmidt" (1986) 86 Colum. L. Rev. 1622 at 1627.

Wilson, supra note 4 at 1-19.

Thornhill, supra note 4 at 1-24. 
signifies a breach of duty, constitutes unethical behaviour and is tantamount to collective professional misconduct.

\section{LAW SCHOOL REALITY}

Let us look, for example, at how the material reality of law schools, the prime gatekeepers of the profession, sets the tone, pace and quality of the professional pathway for every student and colours their trajectory throughout the study and practice of law. ${ }^{23}$ A 1992 Justice Canada report surveying ten law schools in Canada concluded that discrimination attributed to race or ethnicity both observed and experienced by "Visible Minorities" and First Nations peoples was reported: outside the law school; within the law school, perpetuated by both students and professors alike; and also during the application for admission process. ${ }^{24}$ How really cognizant are we of the various law school indicia which reveal the myriad ways in which factors of race and colour define how our profession is organized and determine quality of access, progress and success?

Attempts and initiatives to set in place recourses of redress and protection against harassment and discrimination all too often meet with a stone wall of opposition cloaked in ostensibly non-racial concerns such as "academic freedom," "political correctness," "myth of meritocracy".... ${ }^{25}$ Objections and resistance to these initiatives, which are themselves geared towards broadening access, come deeply intertwined with widespread conceptions of opportunity and privilege and those (mis)perceived threats to existing benefits, "prior claims" and acquired entitlement. ${ }^{26}$

Be they affiliated with a special, equal opportunity, or equity admissions program or not, the sight and presence of "Visible Minority" students in law faculties all too often trigger a vicious stigmatization and smear campaign wherein White co-students, (mis)perceiving that their own unspoken group interest and "prior" claim are being threatened, set about labelling their minority peers as "unqualified," "incompetent," "inferior," "lesser," "unworthy"...; in short, "unentitled" to a rightful place in law school.

As Professor Kimberlé Williams Crenshaw so accurately points out, there prevails in current law a dominant group perspective which confers upon itself at one and the same time a normative value and a perspectiveless nature. ${ }^{27}$ In legal inquiry, minority perspectives are excluded and dominant group perspectives privileged; in the discussion of doctrine, minority perspectives are devalued while dominant group perspectives hold

24 C. Meredith \& C. Paquette, Survey of Students at Ten Law Schools in Canada (Ottawa: Department of Justice Canada, Research and Development Directorate, 1992). (1987) $43: 1 \mathrm{~J}$. of Social Issues 41 at 48. 
up the frameworks; and in the construction of paradigms and legal theory, "minority" perspectives are excluded and dominant group perspectives hold sway. ${ }^{28}$

Law school curricula at all levels of education are grounded within a white patriarchal middle-class system of values that "disappears" or erases other world views in an unquestioned belief in the "unchallengeable" universality of the dominating Eurocentric experience. To be accepted as a deserving team member and "play the game right," minority students have to shroud themselves in suffocating denial and adopt as their starting point, a distanced, far-removed - and therefore "objective" posture. ${ }^{29}$ The nature and structure of curriculum content engenders discussions that focus exclusively on problems, interests and values that either do not share or that obscure or overlook issues which are particularly relevant to "Visible Minority" students. ${ }^{30}$ Right now, most minority students go through law school bereft of role models; they experience legal education like an out-of-body experience, always feeling that something is missing, forever being reminded by constant daily bombardment that they are outsiders, intruders.... To get through law school, excluded group students are forced to engage in disconnected, disembodied discussions as though they are not black, not aboriginal, not of Asian ancestry, not disabled, not female..., but rather colourless neutered legal analysts. ${ }^{31}$ To get through law school, minority students must run the gauntlet of objectification, ${ }^{32}$ subjectification, ${ }^{33}$ invisibility, alienation ${ }^{34}$ and isolation. Current Canadian law school curricula and legal scholarship offer no safe harbour in which minority students can anchor their own experiences, no solid moorings to which they can ground their analyses. ${ }^{35}$ Narrowly constructed boundaries of classroom decorum not only penalize analyses predicated on individual and collective factual experiences, but also immunize law from serious criticism, unless the student dares to strike out against the current and run the risk of being labelled "emotional," "hysterical," "irrational" and (heaven forbid) "un-lawyerlike." ${ }^{36}$

Even though in this hemisphere and in this country the centrality of "race" is critical to and should inform the teaching of law, ${ }^{37}$ as legal educators and practitioners we are for the most part still largely unequipped with the know-how for creating the necessary space and legitimizing the responses which acknowledge and validate "the significance of a racially informed perspective." ${ }^{38}$ And yet, we would all undoubtedly concur that Law should be liberating and emancipatory for everyone, ${ }^{39}$ including heretofore

Williams Crenshaw, ibid.

Jbid. at 5, 12.

Ibid. at 9.

Ibid. at 3,8 .

Ibid. at 3-6.

Ibid. at 6-9.

Ibid. at 9-10.

Ibid. at 12.

Ibid. at 4.

Thornhill, supra note 4 at 14 .

Ibid. at 5.

E.M.A. Thornhill, So Seldom for Us, So Often Against Us: Being Black and Living with the Canadian Justice System (Montreal: Education Department, Quebec Human Rights Commission, 1989). 
excluded groups. Indeed, "Visible Minority" law students, among others, should also be able to celebrate Law, as satisfied service users and as productive legal professionals. For in the words of Professor Sidney Willhelm, "the myth of equality within a context of oppression will simply provide a veneer for more oppression."140

\section{CONCLUSION}

"Equality without an income is of little value."41 Equality in the legal profession signifies substantive equality, which encompasses, in addition to intent and process, outcomes and consequences and the right to an equal economic opportunity. Equality means opening up access. Equality in the legal profession means that the recourses and procedures on the books should be accessible to, and should work for, "racialized" minorities seeking redress, remedy, relief or reparation. Equality in the legal profession means that law and the legal profession need to respond concretely and meaningfully to the very visibly changed face of Canada and inclusively allow diversity to enrich the ranks, vision, perspectives, constructs and analytical frameworks of Canadian law. For, according to the predictions of futurists, "Visible Minorities" who already constitute the world majority will comprise a critical mass in the workforce of the twenty-first century; and North American societies are going to have to rely increasingly on the very groups that have been discriminated against in the past. ${ }^{42}$ It is therefore against this compelling backdrop that our profession needs to address the issue of access, as a fundamental question of ethics within the legal profession.

Cited in D. Bell Jr., Civil Rights in 2004: Where will We Be? Working Paper CR-2 (College Park, Maryland: University of Maryland Centre for Philosophy and Public Policy, 1985) at 7.

12 J.E. Tucker, "The 90s: Time To Fulfill the Dream" (1990-1991) 17:4 J. Intergroup Relations 10 at 13 . 